\title{
Lexical Expressions of Path Motion in Vietnamese: A Perspective from Cognitive Linguistics
}

\author{
Ly Ngoc Toan \\ Lac Hong University, Vietnam \\ lytoandhcs75@gmail.com
}

\begin{tabular}{|c|c|}
\hline $\begin{array}{l}\text { Received: } \\
\text { 07/06/2019 }\end{array}$ & $\begin{array}{l}\text { Abstract } \\
\text { The aim of this paper is to study the semantics and syntax of lexi }\end{array}$ \\
\hline $\begin{array}{l}\text { Published: } \\
\text { 20/06/2019 }\end{array}$ & $\begin{array}{l}\text { expressions of path motion in Vietnamese. This paper is conducted on theory } \\
\text { of lexicalization patterns which is related to the conflation of semantic } \\
\text { components into linguistic units. The data are the expressions of motion verbs }\end{array}$ \\
\hline $\begin{array}{l}\text { Keywords: } \\
\text { Path Motion, } \\
\text { Lexicalization Patterns, } \\
\text { Conflation, } \\
\text { Lexical Expression }\end{array}$ & $\begin{array}{l}\text { and spatial prepositions which were taken from } 12 \text { Vietnamese stories and } \\
\text { three novels in the 20th century onward. The result of this paper presents } \\
\text { several lexicalization patterns of semantic components conflated into the path } \\
\text { verbs and the spatial prepositions. Moreover, this paper takes into account the } \\
\text { construction of the grammar of the lexical expressions of path motion in } \\
\text { Vietnamese, which refers to speakers' knowledge of motion utilized to express } \\
\text { motion. }\end{array}$ \\
\hline
\end{tabular}

\section{INTRODUCTION}

Cognitive linguistics is an approach to the language study viewing linguistic knowledge as part of general cognition and thinking; linguistic behavior is not separated from other general cognitive abilities allowing mental processes of reasoning, memory, attention and learning, but understood as an integral part of it. Cognitive linguistics has had a profound impact on the study of language in terms of both semantics and grammar from the 1980s onward. It is holding the evidence that language is learned and processed much in the same way as other information about the world, and that the same cognitive processes are involved in language and other forms of thinking (Taylor \& Littlemore, 2014, p. 1). As a result, Evans \& Green (2006, p. 5) concludes that to study language from this perspective is to study patterns of conceptualization. That is, language provides windows into cognitive functions and insights into the nature, structure and organization of thoughts and ideas.

Motion is a domain in language which has been particularly attractive since it has been said to be one of the primary experiential domains in human life and bound to be lexicalized in all languages. For this reason, an investigation into motion from the perspective of cognitive linguistics is indispensable, which takes into account for the relationship between language and thought. This will shed light on the role of thought in shaping language. More importantly, this analysis will help to expound different explanations of motion from different cultures.

One of the most dominant works associated with the field is Talmy's (1985) binary typology. In this research, Talmy delved into the relationship between surface forms and semantic components. More precisely, he examined the way of how many semantic components are expressed by different surface forms and vice versa. He also termed this process as lexicalization, which means the ways experience is rendered into languages via the semantic content of lexical items that are used to express experiential categories (Talmy, 1985). He arrived at the conclusion that the relation between surface forms and semantic semantic components is not one-to-one. That is, one semantic component could be expressed more than one surface forms and vice versa. 
Talmy's seminal work has engendered a number of studies in the literature on motion event descriptions across languages over the last two decades. However, these studies mostly revolve an exploration into semantic properties of motion verbs and prepositions in isolation, hardly any studies have been devoted to an in-depth investigation into a thorough conglomerate of combination between motion verbs and spatial prepositions. This is the reason why the study with title "Lexical expressions of path motion in Vietnamese (LEsPM): A perspective from cognitive linguistics" has been chosen for the current study.

\section{THEORETICAL BACKGROUND}

\subsection{Talmy's theory of lexicalization patterns}

Talmy (2000) delves into the exploration of systematic relations between semantic components and linguistic forms, in other words, into the process of lexicalization. Talmy (2000b, p. 24) posits that lexicalization is involved where a particular meaning component is found to be in regular association with a particular morpheme. Talmy shows that there are two directions which can be adopted for investigating the meaning and linguistic form relations. One direction is to keep constant a selected surface or linguistic entity, and then observe which semantic entities are variously expressed by it. Another direction is to hold particular semantic entities constant, then observe the surface or linguistic entities in which it can appear. Talmy proposes the two typologies: (i) the three-way classification (Talmy, 1985) and (ii) the two-way classification of languages (Talmy, 1991, 2000b).

\subsubsection{The three-way typology}

This typology stems from examining which semantic components are characteristically lexicalized in motion verbs in several languages. Three principal lexicalization types are presented by motion verbs expressing the Co-event (Manner or Cause), the Path, or the Figure. Talmy (2000b, p. 27) concludes that a language utilizes only one of these types for the motion verbs in its most characteristic expression of Motion which means that (i) it is colloquial in style, rather than literary; (ii) it is frequent in occurrence in speech, rather than only occasional; (iii) it is pervasive, rather than limited.

\section{a. Lexicalization patterns: Motion + Co-event}

In this expression, the verb typically denotes at once the Motion and a Co-event which are usually either the Manner or the Cause. English is one of the prototypical examples of this group. Talmy (2000b, p. 28) summarizes English expressions of Motion conflated with Manner or Cause as follows:

\section{Move + Manner}

\section{Non-agentive}

(1) a. The rock slid/rolled/ bounced down the hill.

b. The gate swung/ creaked shut on its rusty hinges.

c. The smoke swirled/squeezed through the opening. Agentive

d. I slid/ rolled/ bounced the keg into the storeroom.

e. I twisted/ popped the cork out of the bottle.

Self-agentive

f. I ran/limped/jumped/stumbled/ rushed/groped my way downstairs.

\section{Move + Cause}

g. She wore a green dress to the party.

\section{Non-agentive}

h. The napkin blew off the table.

i. The bone pulled loose from its socket.

$\mathrm{j}$. The water boiled down to the midline of the pot. Agentive

k. I pushed/threw/ kicked the keg into the storeroom. 
1. I blew/flicked the ant off my plate.

$\mathrm{m}$. I chopped/sawed the tree down to the ground at the base.

$\mathrm{n}$. I knocked/ pounded hammered the nail into the board with a mallet.

In this point, it is crucial to define the terms such as agentive, non-agentive and self-agentive motion. First, agentive motion is associated with a motion event whose Figure is moved by an agent; the agent causes the motion but the verb can denote either its Cause or the Manner in which the Figure moves. Second, non-agentive motion refers to the situations in which entities that are incapable of performing motion by themselves. Finally, self-agnetive motion has to do with events in which Figure are able to move by themselves.

\section{b. Lexicalization patterns: Motion + Path}

In the second expression, the fact of Motion and Path are conflated into the motion verbs. Talmy (2000b, pp. 49-51) points out that Spanish is the most typical language whose expressions of Motion are conflated with Path. In the case of Vietnamese, there is a group of verbs termed as the directional verbs such as (e.g., vào, ra, lên, xuống, qua, lại, tới. etc) which conflate with the Path (Nguyễn Lai, 2001). This can be illustrated by the examples below:

Non-agentive

(2) a. Tiếng động vang dội vào tận lèn đá.

b. Bao nhiêu gánh xiếc tới Huế.

Agentive

c. Lượm tụt xuống hố, khéo léo lắm mới gạn được nửa ống bơ nước bùn.

d. Một lúc sau, Mực lại gần tôi.

In reality, though English also has verbs which incorporate Path such as arrive, approach, cross, ascend, circle, descend, enter, exit, follow, join, pass, rise, return, etc., this lexicalization pattern is not characteristic. This is because these verbs are historic borrowings from Romance languages. Talmy (2000b, pp. 62,139) adds that this conflation pattern (Motion +Path) hardly expands to conflation of location with site, which is "Be-on", "Be-under", etc, despite the fact that English consists of some incidental cases of such conflation such as surround (be around), top (be atop), flank (be beside), adjoin (be next to), span (be from one side to the other) and line (be in line).

\section{c. Lexicalization patterns: Motion + Figure}

In this pattern, the motion verbs conflate Motion and Figure. English has got a few forms which conform to these patterns. English examples of conflation of Motion and Figure are taken from Talmy (2000b, p. 57).

Non-agentive

(3) a. It rained in through the bedroom window.

\section{Agentive}

b. I spat into the cuspidor.

Likewise, Vietnamese also has a few forms that conflate the two semantic components. Examine the following examples:

Non-agentive

(4) a. Cả đội ùa hết ra sân mặc dầu trời vẫn lắc rắc mura.

Agentive

b. Tên cai ngục khạc nhổ, đóng ập cửa lại, đập chốt sắt.

\subsubsection{The two- way typology}

An exploration into two-way typology is to look at the morphosyntactic constituents that characteristically encode the component of Path in a motion event. Hence, the Path component emerges in the path verbs in verb-framed languages, but it is lexicalized in the satellites in satelliteframed languages.

In this point, a satellite is the grammatical category of any constituent that is in a sister relation to the verbs (Talmy, 2000b, p. 102). In English, satellites can be prepositions (into, out of, around, across, etc) or particles (e.g., up, out, away, etc), in contrast, satellites in Vietnamese can be both the 
directional verbs (e.g., vào, ra, lên, xuống, tới, lui, về, qua, sang, etc) and prepositions (e.g., quang, doc theo).

Talmy (1991, 2000b) proposes that motion events in which Path is characteristically expressed is to an extent where aspect, change of state, action correlation and realization are characteristically encoded as well. On the other hands, the two-way typology for motion events extends to at least four types of events. Accordingly, V-framed languages characteristically lexicalize the trajectory of motion, aspect, change of state, action correlation and realization in the path verbs, whereas it is denoted by verb particles or prepositions in S-framed languages. A few of examples of English are taken from Talmy (2000b, p. 72) to illustrate these points.

\section{Change of state}

a. I blew out the candle.

b. I burned him to death.

\section{Action correlation}

(6). a. I played the medoly along with him.

b. I outplayed him.

Some examples of Vietnamese sharing this point are examined:

\section{Change of state}

(7) a. Xoan loạng choạng bước ra khỏi buồng giam.

\section{Action correlation}

b. Anh mừng đến chảy nước mắt.

(8) a. Nó cắm cổ chạy dọc theo lề đường.

b. Các bạn bơi xúm lại quanh nó.

In short, in English, changes of state and action correlation are expressed with the verb particles or satellites, while the main verb encodes the Co-event (Manner or Cause). However, in Vietnamese, changes of state and action correlation can be expressed with both the path verbs ( $r a$, đến) and prepositions (doc theo, quanh).

\subsubsection{Equipollently-framed languages}

The advent of Talmy's typology of verb-and satellite-framed languages has given rise to a wide range of studies on motion event descriptions in a great number of languages. However, according to Slobin (2004) and Zlatev \& Yangklang (2004) and some other authors, there are several languages which do not assort with Talmy's two-way typology because these languages encode both Manner and Path in the same linguistic forms like in the Vietnamese language.

In the attempt to account for such linguistic diversity, Slobin $(2004,2009)$ proposed one more typology of motion- event construction, which is termed as a tripartite typology of motion events in a so-called equipollently-framed language. In equipollently-framed language, Manner and Path are expressed by the equivalent grammatical forms. More precisely, the Paths in the language are both in the path verbs, prepositions or other linguistic units. This typology seems to fit into Vietnamese, thus when analyzing LEsM in Vietnamese, these properties will be applied. Slobin (2006a, p. 64) suggests three subtypes of equipollently-framed languages.

\section{a. Serial- verb languages}

Serial-verb languages are those languages in which the serial verb construction is a syntactic phenomenon in which two or more verbs or verb phrases are strung together in a single clause.

\section{b. Bipartite verb languages}

Bipartite verb languages are those languages in which the verb consists of two morphemes of equal status, one expressing Manner and the other expressing Path.

\section{c. Generic verb languages}

Generic verb languages are those languages in which the verb is combined with satellite-like elements or coverbs, which encode both Path and Manner in the same fashion. 
In short, English does not consist of any forms of this typology. Meanwhile, Vietnamese does not only fit into Talmy's binary typology (verb-and satellite-framed languages), but it assorts with Slobin's tripartite typology (equipollently-framed language) as well.

\subsection{Lexical expressions of path motion}

According to Lobner (2002: 9), an expression is just a general term for words, phrases and sentences, and expression meaning covers, in particular, word meaning and sentence meaning. Therefore, an expression may be a word (1a), a phrase (1b) or a sentence (1c) in terms of syntax.
a. walk
b. walk to school
c. We walk to school.

Besides, Payne (2011, p. 10) notes that there are three types of expressions in which language allows speakers to express variations and a conceptual category in meaning. He adds that lexical expression is any formal expression of a conceptual category which simply must be memorized, rather than constructed according to a pattern. Payne (ibid: 33) posits that the conceptual category in this definition describes some specific elements of meaning that speakers of a language pay special attention to in terms of grammar. For example, some conceptual categories of the verb "kick" may be understood as a dynamic verb, motion verb, transitive verb and causative verbs, etc.

In addition, Payne (2011) argues that in order to be a conceptual category, a particular element must determine some patterns of grammatical expressions, such as lexical expressions, morphological expressions and syntactical expressions. Therefore, a conceptual category can be a key element to understand the lexical expression. For example, in order to take in the lexical expression of "go to school", it requires us to interpret the conceptual categories in this expression, such as the conceptual category of the verb "go" means the movement from somewhere towards school, and the preposition "to" means direction towards school and on the way to school, etc. More particularly, Payne supports another way to understand the conceptual category is to rely on differences in sets of roots. That is, we can identify differences in the conceptual categories of some verbs by analyzing their roots. For example, the identification of conceptual categories of "go" and "come" is based on the different roots of "go" and "come". The verb "go" means the movement from the speaker to somewhere, and "come" from somewhere to the speaker. As a result, a lexical expression of path motion can be explicated as follows: "A lexical expression of path motion can be a word, phrase, or sentence, which expresses any formal form of a conceptual category of the path verbs and other relevant components, such figure or ground, etc. The path verbs can be transitive and intransitive verbs. When these verbs are intransitive, they generally refer to the acts of motion as in "arrive" as in (10a). Also, when they are transitive, they denote the translational motion as in "left"

as

in

(10b).

(10) a. The mail arrived.

b. He left the house last night.
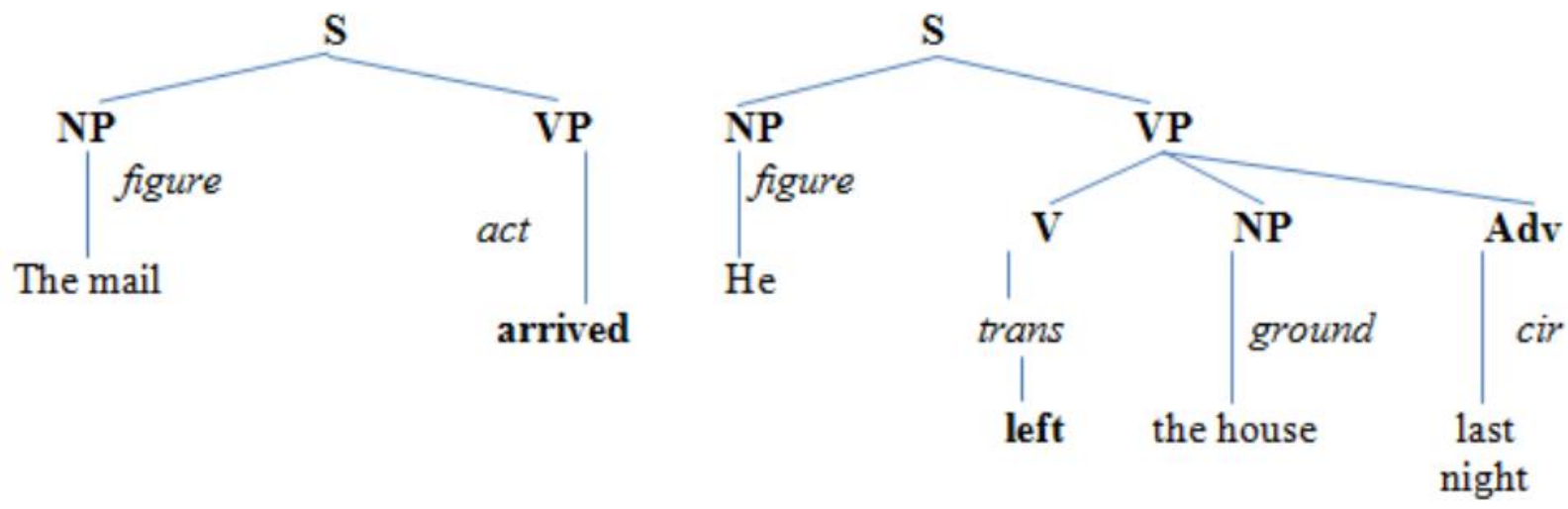
LEs PM in Vietnamese can be schematized as follows.

\begin{tabular}{|llll|}
\hline \multirow{4}{*}{ Subject } & \multicolumn{3}{l}{ A Lexical Expression of Path Motion } \\
\cline { 2 - 4 } & VPedicate of path motion & Periphery \\
\hline He & left & the house & early last night \\
\hline Figure & Motion, path & Ground & Circumstance \\
\hline Arg1 & V & Arg2 & Arg3 \\
\hline A path motion event & & & \\
\hline
\end{tabular}

\section{Figure 1: The Schematization of LEsPM}

\section{RESEARCH METHOD}

\subsection{Data preparation}

The short stories and novels were written in Vietnamese, which are both popular in the contemporary century and written by the different writers in terms of distinct ages and cultures from the $19^{\text {th }}$ century onwards. These stories were coded from VS01 to VS12. These stories and novels were read through to pick up the sentences containing the path verbs and spatial prepositions. These stories and novels were collected which satisfied the three following purposes inquiries: (i) by different authors; (ii) in different historical contexts; and (iii) in different styles.

\section{Table 1. Titles of Vietnamese stories and novels}

\begin{tabular}{lllll}
\hline $\mathbf{N}_{\mathbf{0}}$ & Titles of stories & Authors & Code & Year \\
\hline 1 & Sống mòn & Nam Cao & VS 01 & 1956 \\
2 & Vợ nhặt & Kim Lân & VS 02 & 1962 \\
3 & Bất khuất & Nguyễn Đức Thuận & VS 03 & 1967 \\
4 & Tuổi thơ dữ dội & Phùng Quán & VS 04 & 1968 \\
5 & Dấu chân người lính & Nguyễn Minh Châu & VS 05 & 1972 \\
6 & Sông núi Điện Biên & Trần Lê̂ Văn & VS 06 & 1979 \\
7 & Bí mật của một võ sĩ & Nguyễn Nhật Ánh & VS 07 & 1989 \\
8 & Ăn mày dĩ vãng & Chu Lai & VS 08 & 1991 \\
9 & Phố nhà binh & Chu Lai & VN 09 & 1992 \\
10 & Người không cô đơn & Minh Chuyên & VS 10 & 1995 \\
11 & Ông già và đấu sĩ & Trần Văn Thước & VS 11 & 1998 \\
12 & Chút phấn của đời & Nguyễn Khải & VS 12 & 1999 \\
& & & & \\
\hline
\end{tabular}

\subsection{Data analysis}

After the data are collected, the researcher began to analyze the data according to these approaches; they helped the researcher identify procedures to collect the data, analyze the data and to locate the problems of the study, as well.

\subsubsection{Quantitative approach}

First, the quantitative approach ratifies the completion of a statistical analysis helping to provide essential statistical evidence for the generalization of common features of LEsPM in Vietnamese. It is first used to figure out the frequency of motion verbs in LEsPM so that we can arrive at a conclusion on what is the typical property of LEsPM. Also, it is harnessed to discover the most 
commonly used linguistic properties of LEsPM. The findings are crucial in providing an in-depth interpretation of LEsPM.

\subsubsection{Qualitative approach}

The qualitative technique plays a crucial part in this research. First, the qualitative method helped the researcher to identify research steps and procedures from the theories of cognitive linguistics and the previous studies on analyzing motion. Then, these steps and procedures enabled the researcher to select the data by reading through the English stories. The data analyses would, then, allow the researcher to identify the properties of verbs in LEsPM. Afterward, LEsPM continued to be analyzed to find out theories and hypothesis including the syntactic and semantic features.

\section{FINDING AND DISCUSSION}

This section is concerned with the semantic and syntactic properties of LEsPM in Vietnamese. The syntactic properties are conducted on the basis of the theory of grammar construction related to the form and meaning relation. Next, the semantic properties are associated with the lexicalization patterns of semantic components mapped on the surface forms.

\subsection{Construction grammar of LEsPM in Vietnamese}

This part explores the form-meaning correspondences of LEsPM in Vietnamese. This exploration includes: (i) the arguments arranged around the path verbs; and (ii) the information of different situations packed in the path verbs.

\subsubsection{Argument Structures of LEsPM in Vietnamese}

Table 2 summarizes the argument structures of LEsPM in Vietnamese, which is grouped into four categories; (i) numbers of arguments in each expression, (ii) types of arguments; (iii) the number of verbs; and (iv) distribution of each type.

Table 2. Argument structures of LEsPM in Vietnamese

\begin{tabular}{clcc}
\hline Number of Args & Argument structures & Verbs & $\%$ \\
\hline & & & \\
1 & a. V[Figure] & 18 & 47.3 \\
2 & b.V[Figure Place] & 11 & 28.9 \\
& c.V[Figure Ground] & 23 & 60.5 \\
& d. V[Figure Path] & 17 & 44.7 \\
& e.V[Figure Ground Manner] & 9 & 23.6 \\
\hline
\end{tabular}

\section{a. V [Figure]}

The path verbs in this structure are the intransitive path verbs because they have one argument of the Figure. This structure denotes that the motion of the Figure is considered a result, but not a process. As a result, the Ground as well the Path is not mentioned. There are 18 path verbs, making up 47.3\%, found in the data (e.g., biến khỏi, co quắp, đế, đến gần, đi, đi đầu, đi khỏi, ha cánh, lên, lùi, nhập cur, ra, tản cur, tới, trở lại, trốn thoát, vào and xuống) in this structure. Take (5.21) as an example, in which $E m$ is the Figure and $\boldsymbol{d i}$ is motion.

\section{(11) Em không đi.}

\section{b. V [Figure Place]}

This structure denotes that the motion takes place in harmony with the Ground. In other words, the Figure's motion is limited by that Ground, so this structure does not include the Path and Ground. There are 11 path verbs found in the data, occupying 28, 9\%, in this structure (e.g., dạo, di, dọt 
kích, gục, hạ cánh, lùi, ra, trốn thoát and vào) with two arguments such as the Figure một bóng ngươi $i$ and the Place trong ngõ.

(12) Bỗng một bóng người cứng nhắc xồng xộc vào trong ngõ.

\section{c. V [Figure Ground]}

There are 23 the path verbs, making up $60.5 \%$ consisting of two arguments, which are the Figure and the Ground. Thus, these path verbs are the transitive path verbs (e.g., bỏ xa, cập, cúi, dạo, đến, đến gần, đi, đi khỏi, đột kích, ghé, lại, lên, lùi, qua, ra, theo đuổi, tới, trèo, trở lại, trốn thoát, vào and xuống). This structure denotes that a Figure đò is moving toward the Ground bến làng Trò.

(13) Tảng sáng, đò cập bến làng Trò.

\section{d. V [Figure Path]}

This structure has two arguments, which are the Figure and the Path. In this structure, the Figure refers to the moving object and the Path refers to the direction of motion. The Figure and the Path of motion are more prominent, so the Ground is not mentioned. This expression consists of 17 verbs, making up $44.7 \%$ (e.g., chum, chụm, co, cúi, co quắp, doãi, đi, ghé, gục, khép, khuỳnh, khuỵu, lùi, ngả, ngoảnh, quay and ũơn).

(14) Đi khỏi mấy bước rồi chị còn ngoảnh lại nhìn tôi.

\section{e. V [Figure Ground Manner]}

This structure consists of three arguments including Figure, Ground and Manner in which the Figure denotes the moving object and the Ground denotes the place which the Figure is moving toward. In this case, the path verbs simultaneously denote the direction and the Manner. There are 9 path verbs in Vietnamese found in the data, occupying $23.6 \%$ (e.g., dạo, doãi, di, ghé, khuyu, qua, ra, tói and trở lại). The verb ghé in the following example expresses both the motion and the manner which is not the not official visiting or in a short-timed visiting.

(15) Một chuyến anh được quay trở ra hậu phương và ghé nhà.

\subsubsection{Event structures of LEsPM in Vietnamese}

Table 3 summaries the event structures of LEsPM in Vietnamese, which is grouped into three categories such as (i) types of events; (ii) semantic features; and (iii) the path verbs denoting each of events.

Table 3. Event structures of LEsPP in Vietnamese

\begin{tabular}{llcc}
\hline \multicolumn{2}{c}{ Event structures } & Verbs & \% \\
\hline a. States & $\begin{array}{c}\text { Atelic } \\
+ \text { Stages }\end{array}$ & 0 & 0 \\
\hline b. Activities & $\begin{array}{c}\text { Atelic } \\
\text { - Stages }\end{array}$ & 10 & 26.3 \\
\hline c. Achievements & $\begin{array}{l}\text { Telic } \\
\text { - Stages }\end{array}$ & 26 & 68.4 \\
\hline d. Accomplishments & $\begin{array}{l}\text { Telic } \\
+ \text { Stages }\end{array}$ & 2 & 5.2 \\
& & & 100 \\
\hline
\end{tabular}

\section{Total}

38

100

\section{a. Event of States}

This event refers to the two semantic features such as Atelic and -Stages. The first feature refers to the motion which does not need to contain an endpoint. The second feature postulates that the event of States is stative situations. As a result, there are no verbs found in the data denoting this event.

\section{b. Event of Activities}


This event has two semantic features such as Atelic and -Stages. First, the Atelic feature depicts that the path verbs do not require an endpoint, so the path verbs denoting event are generally the intransitive path verbs. Next, the -Stages feature refers to dynamic situations in which the path verbs can denote the continuous motion. There are 10 path verbs $(26.3 \%)$ (e.g., chúm, co, doãi, dạo, co quắp and ha cánh, etc) found in the data.

\section{c. Event of Achievements}

The event of Achievements denotes that the Figure of motion is necessary to move toward the Ground. In other words, the path verbs always consist of an endpoint and are transitive verbs as in (17). The -Stage property means that this is dynamic motion, which can be a continuous motion at a certain time. This is the most common event in Vietnamese including 26 path verbs, making up $68.4 \%$ (e.g, biến khỏi, bỏ xa, cuii, đi khỏi, đột kích, ghé and $n g a \hat{a}$, etc).

(17) Anh sẽ ngả con chó nằm ngửa trên một tấm ny lông.

\section{d. Event of Accomplishments}

The last event denotes the motion with an endpoint and an undynamic situation. This event is the least common in Vietnamese, which have 2 path verbs (e.g., khuỳnh and trốn thoát) found in the data denoting this event.

\subsection{Lexicalization patterns of LESPM in Vietnamese}

This section is concerned with the lexicalization patterns of LEsPM in Vietnamese, which will elucidate semantic components conflated into the path verbs such as Path, Manner and Ground and spatial adpositions such as directions and vectors. This is an answer to the question what are lexicalization patterns of LESMM in VN?

\subsubsection{Lexicalization patterns of the path verbs in Vietnamese}

Table 4 summarizes the lexicalization patterns of the semantic components conflated into the path verbs, which are Manner, Path and Ground.

Table 4. Lexicalization patterns of the path verbs in Vietnamese

\begin{tabular}{|c|c|c|c|}
\hline \multirow{2}{*}{$\begin{array}{c}\text { Number of components } \\
\begin{array}{c}\text { Types of } \\
\text { components }\end{array}\end{array}$} & \multirow{2}{*}{ Lexicalization patterns } & \multirow[t]{2}{*}{ Verbs } & \multirow[t]{2}{*}{$\%$} \\
\hline & & & \\
\hline external & a. Motion +Path & 23 & 60.5 \\
\hline & Total & 23 & 60.5 \\
\hline external & b. Motion + Path + Manner & 12 & 31.5 \\
\hline 3 & c. Motion + Path + Ground & 3 & 7.8 \\
\hline & Total & 15 & 39.5 \\
\hline external & d. Motion + Path+ Ground+ Manner & 0 & 0 \\
\hline & Total & $\mathbf{0}$ & $\mathbf{0}$ \\
\hline & Total & 38 & 100 \\
\hline
\end{tabular}

\section{a. Lexicalization Patter: Motion + Path}

In this expression, two semantic components are conflated into the path verbs, which are Motion and Path. There are 23 verbs, making up 60.5\% (e.g., biến khỏi, bỏ xa, dạo and đến, etc). In general, the path verbs in this expression simultaneously denote the motion of the Figure and the path of the motion from the starting point to the Ground as in (18).

(18) Không một thằng địch nào dám đến gần cái đống đất ấy! 


\section{b. Lexicalization Patterns: Motion + Path + Manner}

This expression consists of three semantic components, which are Motion, Path and Manner. There are 12 verbs $(31.5 \%)$ found in the data denoting this expression (e.g., chum, co, cum, uõn and khuỳnh, etc). Take the verb uõn as an example; the path verb denotes that the Motion is the Figure's change of position from one place to another. Next, the Path is the route path which the Figure moves along. Last, the Manner is mostly concerned with the style of motion of the chest.

(19) Nổi xung, em cầm lấy chim, ưỡn người trễ về phía bọn giặc.

\section{c. Lexicalization Patterns: Motion + Path + Ground}

There are three semantic components conflated into the path verbs, namely Motion, Path and Ground. There are three verbs, making up $7.8 \%$ found in the data (e.g., cập, ha cánh and nhạp $c u$ ). These path verbs denote that the Figure moves from one position to another along a path xuống toward the Ground as in (20).

(20) Tại sao máy bay vận tải lẻ tẻ còn hạ cánh xuống sân bay được?

\section{d. Lexicalization Patterns: Motion +Path + Ground + Manner}

The four semantic components conflated in the path verbs, which are Motion, Path, Ground and Manner. However, there are no path verbs in Vietnamese denoting four semantic components at the same time.

\subsubsection{Lexicalization patterns of Path in Vietnamese}

This section is concerned with an investigation into the semantic components in terms of directions conflated into the path verbs in Vietnamese. Such directions are determined by the relative position between the Figure and Ground. Table 5 summarizes thirteen types of directions between the Figure and the Ground conflated into Vietnamese path verbs.

Table 5. Lexicalization patterns of the paths in Vietnamese

\begin{tabular}{|c|c|c|}
\hline Lexicalization patterns & Verbs & $\%$ \\
\hline a. $V+$ Away from $G$ & 7 & 18.4 \\
\hline b. V+ UP/onto G-Upwards & 2 & 5.2 \\
\hline c. $V+$ After $G$ & 1 & 2.6 \\
\hline d. $V+$ Change direction & 3 & 7.9 \\
\hline e. V+ Down from/to G- Downwards & 5 & 13.1 \\
\hline f. $V+$ To/towards G & 4 & 10.5 \\
\hline g. V+ Back to G- Backwards & 3 & 7.9 \\
\hline h. $V+$ Pass/cross G & 1 & 2.6 \\
\hline i. $V+$ Into $G$ & 7 & 18.4 \\
\hline j. V+ Closer to $G$ & 1 & 2.6 \\
\hline k. V+ Forwards G & 1 & 2.6 \\
\hline 1. $V+$ Out of $G$ & 1 & 2.6 \\
\hline m. V+ Multiple direction & 2 & 5.2 \\
\hline Total & 38 & 100 \\
\hline
\end{tabular}

\section{a. Lexicalization pattern: $V+$ Away from $G$}

The path verbs denoting this direction consists of 7 path verbs (18.4\%) found in the data such as biến khỏi, bỏ xa, doãi, khuỳnh, tản cu, trốn thoát, and đi khỏi. These verbs denote that the Figure is moving away from the Ground. For instance, Figure Hai nguoòi, at first, is at the place of the Ground Xiêm, but the Figure separated from the Ground and moved away from the Ground di khoi .

(21) Hai người vừa đi khỏi Xiêm đã sập hết các phên cửa.

b. Lexicalization pattern: V+UP/onto G-Upwards 
The verbs with this direction denote that the Figure moves from a low position to a higher position. There are two path verbs (5.2\%) which denote this direction such as lên and trèo. The verb lên expresses the direction of motion from a low position to a higher position; meanwhile, the verb trèo provides some more specific information about motion such as from a low position to a higher position, a vertical direction, an animate Figure and motion with legs and arms as in (22).

(22) Lượng trèo (lên) những bậc đá.

\section{c. Lexicalization pattern: $V+$ After $G$}

There is only one verb theo denoting this Path found in the data in Vietnamese. This verb denotes that Figure Chi em is moving after the Ground Bộ độ $i$ which may (not) be moving at the same time.

(23) Chị em chỉ có thể bố trí từng tốp theo Bộ đội.

\section{d. Lexicalization pattern: $V+$ Change direction}

The verbs such as quay, ngoảnh and nghé denote that the Figure is moving according to a certain direction but urgently changes its direction. The verbs quay and ngoanh reveals that the second direction is completely opposite to the first direction as in (24a). The verb ghé means the Figure may turn left or turn right, so the Figure in this expression must be agentive subject as in (24b).

(24) a.Kinh quay người và nói nhỏ hơn.

b. thấy rứa, nó cũng tò mò ghé lại coi chút cho biết.

\section{e. Lexicalization pattern: V+Down from/to G-Downwards}

There are six verbs (15.7\%) denoting this direction found in the data such as xuống, ngả, khuyu, hạ cánh, gục and cúi. The verb ha cánh denotes the vertical direction from a high position to a low position, but other verbs do not. More specially, the Figure of the verb

ha cánh must be a type of machine like planes. The verbs xuống, ngả, cúi and khuỵu denote the directions of the curve.

\section{f. Lexicalization pattern: $V+$ To/towards $G$}

The verbs with this direction denote mean that the Figure is moving in the direction of the Ground and approaching it. There are four verbs of Vietnamese path verbs $(10.5 \%)$ found in the data denoting this direction, namely tói, đi, đi đầu, and đến. There is a difference between the verb đi and đến. The verb đi denotes that the Figure moves from the speaker to the hearer, but the verb đến from the hearer to the speaker. More specially, the verb đi đầu depicts that Figure is standing in the first position and moving in the direction of the Ground.

\section{g. Lexicalization pattern: $V+$ Back to G-Backwards}

The verbs with this direction posit that the Figure is at the same place as the Ground, and then the Figure is moving towards the Ground. There are three path verbs (7.8\%) found in the data, namely lùi, lại and trở lại. The verbs lùi and lại express the direction of the Figure towards the Ground while the verb trở lai does not only denote the direction of the Figure but the starting point and the destination as well.

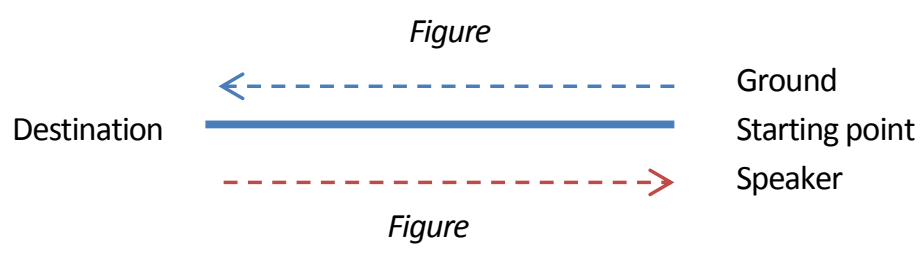

Figure 2. The direction conflated into the verb trở lại

\section{h. Lexicalization pattern: V+ Pass/cross $G$}

There is one verb (2.6\%) denoting this direction in Vietnamese, which is qua (băng qua). This direction means that the Figure (the arrow) may move from one side to another of the Ground as Figure 3, move into at one side and out of at another side of the Ground as Figure 3, or move parallel with the Ground as Figure 3c. In this expression, the sides of the Ground play an important 
role in determining the starting point as well as endpoint of motion, especially the limitation of Figure's movement. In reality, the Ground plays a role as the Path.

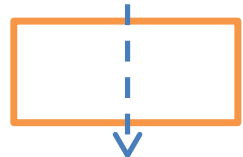

(a)

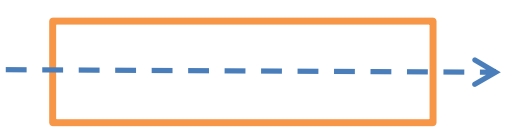

(b)

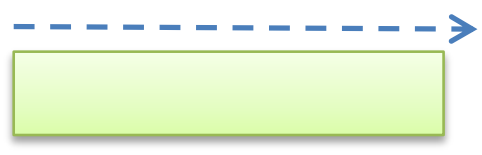

(c)

Figure 3. The direction conflated into the verb qua

\section{i. Lexicalization pattern: $V+$ Into $G$}

There are seven path verbs (18.4\%) found in the data denoting this direction, namely vào, nhập cu, co quắp, co, chụm, chúm and cập. The verb vào denotes the direction from the outside part to the inside part of the Ground. The verbs co quắp, co, chụm and chúm express the Figure's change of size, which is normally from big size to a smaller size. Next, for the case of the verb nhập cu, the Figure must be the agentive subject, which moves from a country into another. Finally, the verb câp refers to the Figure's motion from the open sea or river to the shore or harbor.

\section{j. Lexicalization pattern: $V+$ Closer to $G$}

The verb with this direction denotes that the Figure is nearing the Ground. There is only one path verb khép expressing this direction found in the data, making up 2.6\%. In this case, there are generally two Figures, which move coincidentally.

\section{k. Lexicalization pattern: $V+$ Forwards $G$}

There is one word found in the data denoting this direction, which is dến gần. When denoting this direction, the Ground is considered to be the destination or the target for the Figure which is moving towards nearer and nearer the Ground from the distance.

\section{l. Lexicalization pattern: $V+$ Out of $G$}

Opposite to the direction into $G$, the verb with this direction expresses the Figure's motion from the inside area to the outside area, and the Ground is regarded as the container. To put it simply, the starting of motion will be certainly inside of the container and the endpoint must be outside the Ground. In addition, this motion is conceptualized as moving from a covered area to an open area. There is one verb found in the data which denotes this direction $(\mathrm{ra})$, which posits that the Figure normally moves from a small area to a larger one as in (25).

(25) Cả đội ùa hết ra sân mặc dầu trời vẫn lắc rắc mưa.

\section{m. Lexicalization pattern: $V+$ Multiple directions}

This verb denoting this direction normally consists of many Figures at the same time, and each of Figures moves in different directions. There are two verbs (5.2\%) with this direction found in the data, which are dạo and di khỏi.

\section{CONCLUSION}

This paper is associated with an investigation into the syntax and semantics of LEsM in Vietnamese. In terms of the syntax, LEsM is analyzed on the theory of construction grammar which points out speakers' knowledge of LEsM including argument structures and event structures. In the first place, the argument structures of LEsM are concerned with the syntactic aspects of the path verbs. To be more precisely, the arrangement of motion elements (e.g., Figure, Ground, Path and Motion) with motion verbs. In this paper, there are five argument structures which were found in the data. Next, the event structures of LEsM pertain to the lexical aspects of path verbs. That means, an investigation into the 
components of lexical meanings conflated into the path verbs in Vietnamese was conducted. Semantically speaking, this paper does with theory of lexicalization patterns which refers to the conflation of semantic components in motion events are lexicalized into the path verbs. More particularly, this paper also delves into the conflation of semantic components into the spatial prepositions.

\section{References}

Taylor, J.R \& Littlemore, J. (2014). The Bloomsbury companion to cognitive linguistics. New York: Bloomsbury.

Evans, V \& Green, M. (2006). Cognitive linguistics: An introduction. Edinburgh: Edinburgh University Press.

Talmy, L. (1985). Lexicalization patterns: Semantic structure in lexical forms”. In T. Shopen (Ed.), Language typology and lexical descriptions: Vol. 3.Grammatical Categories and the Lexicon. Cambridge: Cambridge University Press.

Talmy, L. 2000b. Toward a cognitive Semantics: Vol. II: Typology and process in concept structuring. Cambridge, MA: MIT Press.

Talmy, L. (1991). Path to realization: a typology of event conflation. Proceedings of the Seventeenth Annual Meeting of the Berkeley Linguistics Society: General Session and Parasession on the Grammar of Event Structure (1991), pp. 480-519.

Nguyễn Lai. 2001. Nhóm từ chỉ hướng vận động. Tiếng Việt hiện đại. Hanoi: NXB Khoa Học Xã Hội.

Slobin, D. I. (2004). The many ways to search for a frog: Linguistic typology and the expression of motion events. In S. Strömqvist \& L. Verhoeven (Eds.), Relating events in narrative: Typological and contextual perspectives in Translation. Mahwah, NJ: Lawrence Erlbaum Associates.

Zlatev, J., \& Yangklang, P. (2004). A third way to travel: The place of Thai and serial verb languages in motion event typology. In S. Stromqvist \& L. Verhoeven (Eds.), Relating events in narrative: Typological and contextual perspectives. Mahwah, NJ: Lawrence Erlbaum Associates, pp.159190.

Slobin, D.I. (2006a). What Makes Manner of Motion Salient? Exploration in Linguistic Typology, Discourse and Cognition. In Maya Hickmann \& Stephane Robert (eds):Space in Language: Linguistic Systems and Cognitive Categories. Amsterdam: John Benjamins

Lobner, S. (2002). Understanding semantics. New York: Routledge.

Payne, Th. (2011). Understanding English grammar: A linguistic introduction. Cambridge: Cambridge University Press. 


\section{APPENDIX}

\section{LEXICAL EXPRESSIONS OF PATH MOTION (LEsPM) in VIETNAMESE}

I. Lexicalization patterns of Semantic components

* 1= Motion + Path

* 2= Motion + Path + Manner

* 3= Motion + Path + Ground

* 4= Motion +Path + Ground + Manner

II. Lexicalization patterns of Paths

* 1= Away from G * 2= Up/ Onto G-Upwards

* 5= Down from/ to G-Downwards

* 9 = Into $\mathrm{G}$

$* 13=$ Multiple directions

III. Argument Structures

$* \mathbf{1}=\mathrm{V}$ [Figure]

$* 3=$ V [Figure Ground]

IV. Event Structures

a. Types of events

$* 1=$ Events of States

* 3= Events of Accomplishments

b. Types of motion

*1= Translational motion
* 6= To/ towards G

* $\mathbf{1 0}=$ Closer to $\mathrm{G}$

* 7= Back to G/ Backwards

*11= Forwards
* 4= Change direction

* 8= Pass/ Cross G

$* 12=$ Out of $\mathrm{G}$
* 2=V [Figure Place]

* 4=V [Figure Path]
* 5=V [Figure Ground Manner]

* 2= Events of Activities

* 4= Events of Achievements

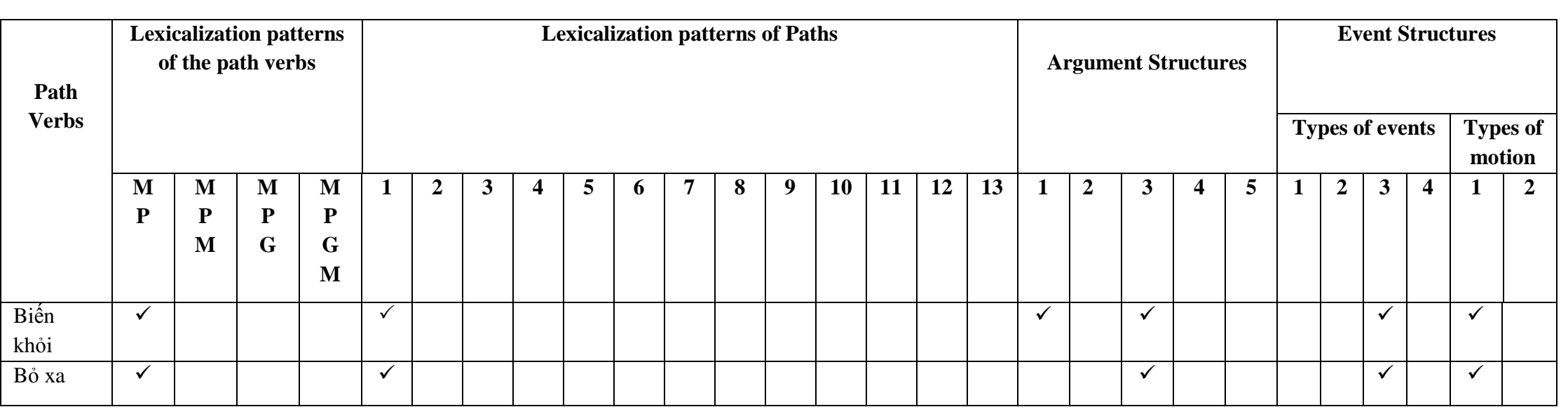


Lexical Expressions of Path Motion in Vietnamese: A Perspective from Cognitive Linguistics

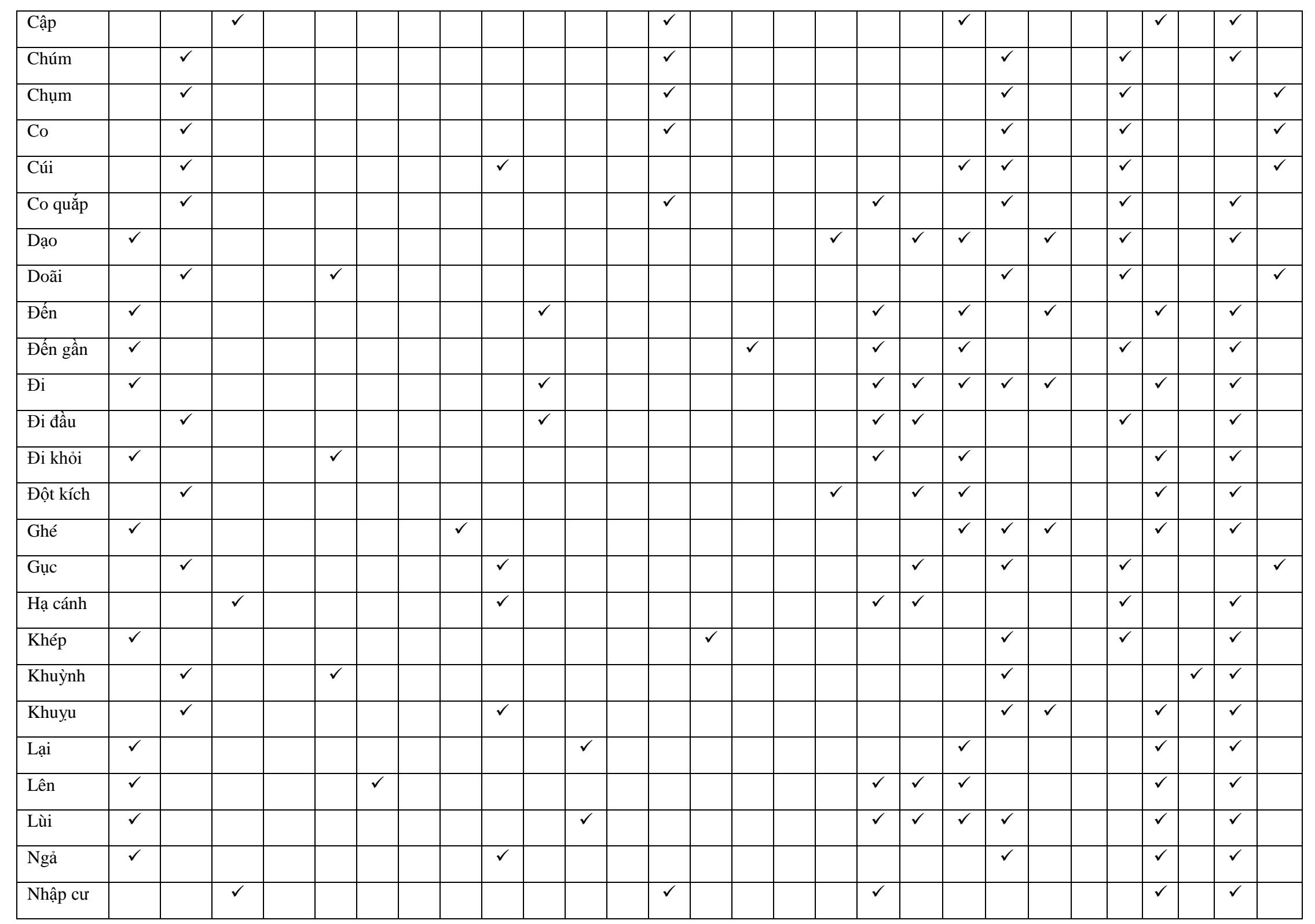




\begin{tabular}{|c|c|c|c|c|c|c|c|c|c|c|c|c|c|c|c|c|c|c|c|c|c|c|c|c|c|c|c|c|}
\hline Qua & $\checkmark$ & & & & & & & & & & & $\checkmark$ & & & & & & & & $\checkmark$ & & $\checkmark$ & & & $\checkmark$ & & $\checkmark$ & \\
\hline Ngoảnh & & $\checkmark$ & & & & & & $\checkmark$ & & & & & & & & & & & & & $\checkmark$ & & & & $\checkmark$ & & & $\checkmark$ \\
\hline Quay & $\checkmark$ & & & & & & & $\checkmark$ & & & & & & & & & & & & & $\checkmark$ & & & & $\checkmark$ & & & $\checkmark$ \\
\hline $\mathrm{Ra}$ & $\checkmark$ & & & & & & & & & & & & & & & $\checkmark$ & & $\checkmark$ & $\checkmark$ & $\checkmark$ & & $\checkmark$ & & & $\checkmark$ & & $\checkmark$ & \\
\hline Tản cư & & & $\checkmark$ & & $\checkmark$ & & & & & & & & & & & & & $\checkmark$ & & & & & & & $\checkmark$ & & $\checkmark$ & \\
\hline Theo & $\checkmark$ & & & & & & $\checkmark$ & & & & & & & & & & & & & $\checkmark$ & & & & & $\checkmark$ & & $\checkmark$ & \\
\hline Tới & $\checkmark$ & & & & & & & & & $\checkmark$ & & & & & & & & $\checkmark$ & & $\checkmark$ & & $\checkmark$ & & & $\checkmark$ & & $\checkmark$ & \\
\hline Trèo & $\checkmark$ & & & & & $\checkmark$ & & & & & & & & & & & & & & $\checkmark$ & & & & & $\checkmark$ & & $\checkmark$ & \\
\hline Trở lại & $\checkmark$ & & & & & & & & & & $\checkmark$ & & & & & & & $\checkmark$ & & $\checkmark$ & & $\checkmark$ & & & & $\checkmark$ & $\checkmark$ & \\
\hline $\begin{array}{l}\text { Trốn } \\
\text { thoát }\end{array}$ & $\checkmark$ & & & & $\checkmark$ & & & & & & & & & & & & & $\checkmark$ & $\checkmark$ & $\checkmark$ & & & & & $\checkmark$ & & $\checkmark$ & \\
\hline Vào & $\checkmark$ & & & & & & & & & & & & $\checkmark$ & & & & & $\checkmark$ & $\checkmark$ & $\checkmark$ & & & & & $\checkmark$ & & $\checkmark$ & \\
\hline Xuống & $\checkmark$ & & & & & & & & $\checkmark$ & & & & & & & & & $\checkmark$ & & $\checkmark$ & & & & & $\checkmark$ & & $\checkmark$ & \\
\hline Ưỡn & & $\checkmark$ & & & $\checkmark$ & & & & & & & & & & & & & & & & $\checkmark$ & & & & $\checkmark$ & & & $\checkmark$ \\
\hline 38 & 23 & 12 & 3 & 0 & 7 & 2 & 1 & 3 & 5 & 4 & 3 & 1 & 7 & 1 & 1 & 1 & 2 & 18 & 11 & 23 & 17 & 9 & $\mathbf{0}$ & $\begin{array}{l}1 \\
0\end{array}$ & $\begin{array}{l}2 \\
6\end{array}$ & 2 & 30 & 8 \\
\hline
\end{tabular}

